\title{
Fisheries Management under Ecological Interdependence: The Case of European Hake and Blue Whiting Fishery
}

\author{
Marcos Pérez-Pérez, M. Dolores Garza-Gil, Manuel Varela-Lafuente \\ Department of Applied Economics, University of Vigo, Vigo, Spain \\ Email: marcos.perez@uvigo.es
}

How to cite this paper: Pérez-Pérez, M., Garza-Gil, M.D. and Varela-Lafuente, M. (2017) Fisheries Management under Ecological Interdependence: The Case of European Hake and Blue Whiting Fisher. Natural Resources, 8, 569-581. https://doi.org/10.4236/nr.2017.88036

Received: July 5, 2017

Accepted: August 13, 2017

Published: August 16, 2017

Copyright $\odot 2017$ by authors and Scientific Research Publishing Inc. This work is licensed under the Creative Commons Attribution International License (CC BY 4.0).

http://creativecommons.org/licenses/by/4.0/

\section{c) (i) Open Access}

\begin{abstract}
In mixed fisheries where there is an increased ecological interdependence between two or more target species, the possibilities of fishing these species must be determined jointly, since catches of one species will impact the natural growth not only of that species but of the others, as well. The objective of this paper is to develop a predator-prey model for two major species caught by the EU fishing fleet on European Union fishing grounds. The predator and prey's population dynamics follow the Lotka-Volterra equation and are assumed to be logic-based, and a lineal interaction between the predator and prey populations is assumed. Optimal single owner multispecies fishery management is analysed, and the applied model is solved, obtaining the equilibrium value of biomasses, catches, and net benefits of the mixed fishery. The results show that the $M S Y$ of the predator is higher than that estimated by ICES, while $M S Y$ for prey is lower. The sensitivity analysis of the results reveals that the biomass levels of both species decrease as the discount rate increases, while catches increase.
\end{abstract}

\section{Keywords}

Ecological Interdependence, Mixed Fishery, Predator-Prey Model, European Hake, Blue Whiting

\section{Introduction}

The complex series of interactions among a fishery's different species has led an increasing number of scientists to recommend multispecies approaches to fishery management [1] [2]. In practice, fisheries are exploited as a multispecies resource [3]. Biological interactions among fish stocks can dominate the structuring of marine ecosystems and so can strongly affect the population dynamics 
of species [2] [4]. In particular, predation and cannibalism are sources of mortality that can alter a population's size and recruitment (i.e., addition of surviving juveniles to the fishery population) [2] [5] [6] [7]. It follows that fishery management could benefit greatly from better comprehending the role of biological interactions-including trophic (i.e., feeding) relationships-in the resource's dynamics [2].

Development of the current analytical/theoretical framework for proposing management guidelines was based on bioeconomic models that account for the biological and economic aspects, in general, of just a single species, an approach that fails to acknowledge the importance of interactions among the marine community's various components. This state of affairs is due primarily to a lack of knowledge-throughout most of the previous century-regarding stock interactions. Yet marine research in this area has expanded significantly over the past few decades [1]-[6] [8] [9] [10] [11]. Hence we can now extend the classic bioeconomic model by considering the implications of dependencies, both ecological and technological, that arise in multispecies fisheries [12].

Along these lines, attempts have been made to account for ecological and technological interdependencies that result from the extractive activities of fishing fleets, which differ not only in terms of their technological characteristics but also in terms of their targeted species and fish population components [8] [12] [13] [14]. Technological interdependence occurs when fleets of different characteristics-for example, as regards fishing power and/or types of skills usedtarget different components (e.g., juveniles and adults) of the same stock, or different species of a mixed stock [15], and therefore have distinct effects on species populations [16]. Another example of technological interdependence is the fleet that catches species coexisting within the same space regardless of whether or not they are interdependent on an ecological level. Ecological interdependence occurs when there is a certain relationship between two exploited stocks [17] [18] or between two different population segments of the same stock. We define two types of such ecological relationships: competition and predation. Competition is defined as the negative effects on one organism when another organism consumes (or interferers with access to) a needed resource that is in limited supply [19]. This interaction leads to the reduced growth, survival, and/or reproduction of competitors; especially those that are phylogenetically subordinate [20] [21]. Predation is the consumption of one organism (the prey) by another organism (the predator); the latter may be herbivorous, carnivorous, or omnivorous [21].

Fisheries that host a greater number of targeted species face a complicated management problem because more biological parameters must be incorporated in their estimates [12] [22] [23] [24] [25]. Practically speaking, sustainable performance is hard to achieve at the ecological level among all the species in a multispecies fishery [26]. Furthermore, the fact that the management of a multispecies fishery must also incorporate economic variables [11] [12] [22] [27] 
[28], only increases the degree of complexity. Yet it is important to continue developing this approach and urging decision makers to consider it, since catching a greater or lesser number of tonnes of a given species can have serious repercussions for the biomass of other species with which there is a trophic interaction (altering the tonnage would also affect, at least some, within-fishery species that were not "targets"). Such catch differences can ultimately affect the sustainability of the ecosystem and of the enterprises that depend on it.

In this paper, we examine the case of a multispecies fishery with two target stocks that exhibit significant trophic interaction (ecological interdependence) as well as predation: the stock of blue whiting (Micromesistius poutassou) and the stock of European hake (Merluccius merluccius). From [11], we introduce costs dependent on the level of biomass into the net benefits function and estimate the optimum levels for biomass and catches of both species. In Section 2 we describe this fishery, where hake is the predator and blue whiting is the prey. In Section 3 we analyse a management model. It is applied to this mixed fishery in Section 4 , and primary results are summarized in Section 5.

\section{Hake and Blue Whiting Fisheries}

In European waters, hake (Merluccius merluccius) and blue whiting (Micromesistius poutassou) are common commercial species. Both are primarily distributed across the continental shelf, where they spawn during the winter months. As we will see, these two species have a clear predator-prey relationship, as blue whiting is the hake's primary prey.

European hake is widely distributed throughout the North-eastern Atlantic Ocean. It is a demersal benthopelagic species that can reach depths that vary from 30 to 1000 meters, although they generally dwell at depths ranging between 70 to 370 meters. They form schools that stick close to the coastline in the summer and keep a greater distance during the winter. Egg-laying season lasts from January to May in the Bay of Biscay, and from May to July in the Celtic Sea. The European hake, a predator at the top of the Northeast Atlantic demersal trophic pyramid, primarily feeds on other species of fish like anchovies (Engraulisencrasicholus), sardines (Sardina pilchardus), blue whiting (Micromesistiuspoutassou), horse mackerel (Trachurustrachurus) and mackerel (Scomber scombrus). Hake is caught in mixed fisheries-along with blue whiting, megrim, monkfish, and Norway lobsters-by a multi-rigged fleet, using the following fishing methods: bottom trawling with doors, bottom pair trawling, bottom-set longline, and small fixed gillnets. Figure 1 shows that this species has recovered over the last several years after nearly reaching biosafety level limits in the 1990s and after European Union (EU) implemented management plans for this species that were based on the progressive reduction of catches and fishing effort [29] [30]. Total landings have been on an upward trend since 1998, in harmony with the abundance of biomass.

Blue whiting is found throughout the North Atlantic from the Southern Barents Sea and Eastern Norwegian Sea up to Cape Bojador, on the African coast. 


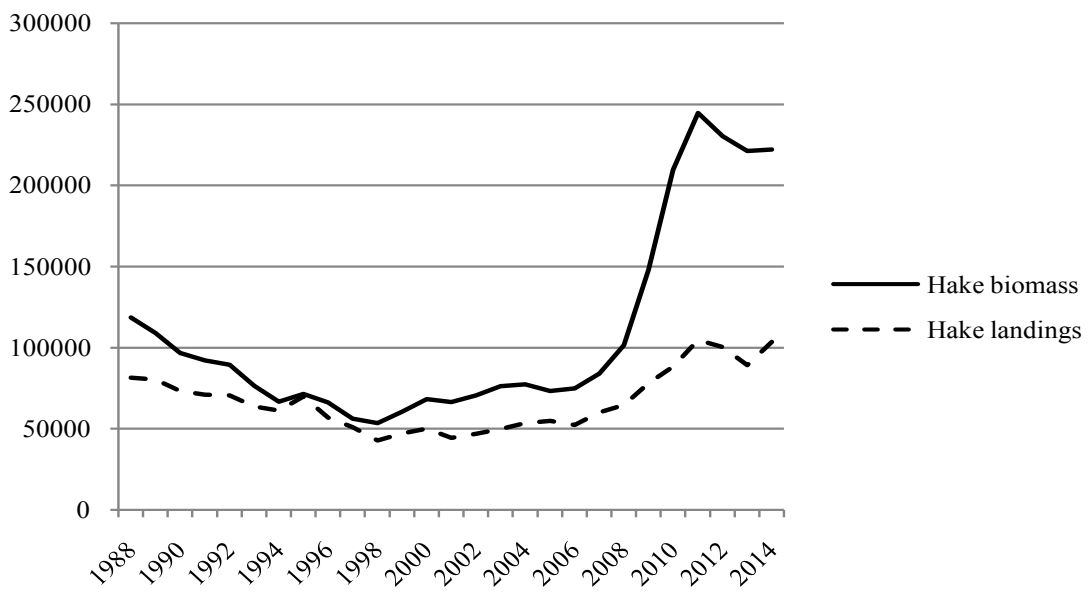

Figure 1. Hake biomass and landings (tons). 1988-2014. Source: Own compilation from ICES (2015 a).

It is a demersal species of the gadus family. Its habitat is the ocean, and as a benthopelagic species, it lives mainly along the continental shelf and slope, distributed vertically at depths of between 150 and 1000 meters, though it is most commonly found at $300-400$ meters below the surface. After laying its eggs, it migrates north in the summer (Faroe Islands, eastern Iceland, and Norway) and returns to the area where it laid eggs in January and February. The eggs are pelagic and hatch between February and June. The main area where eggs are laid is to the west of the British Isles, and their growth is quite rapid. The blue whiting's diet-clearly seasonal-is composed mainly of crustaceans, namely copepods, krill, the larvae of decapods and a decapod known as white glass shrimp (Pasiphaeasivado). Bottom pair trawling is the primary method used to catch blue whiting (it is one of this method's target species) and individual bottom trawling, which picks up the by-catch. The blue whiting's biomass has been significantly reduced over the past several years (see Figure 2). This species plays a major role in fishing quota exchanges between European countries to obtain higher-value species. One such example is the exchanges made between Norway and the EU for higher cod quotas.

The ecological interdependence of the hake and blue whiting populations in European waters has been highlighted by various authors. Reference [31] as well as [32], study the diet of the European hake in the Cantabrian Sea by analysing its seasonal and bathymetric variations and according to the size, which is based on the stomach contents of the sample population. The blue whiting is noted as the hake's primary prey. The regression analysis of the predator-prey size relationship confirms a significant correlation between hake size and blue whiting size [9] [33]. These authors also observed that hake is far more dependent upon blue whiting in the Cantabrian Sea than in the northern part of the Bay of Biscay [2] confirmed these results by showing that the blue whiting is the species upon which the hake most commonly preys in the Cantabrian Sea, though its importance as prey is moderate in the northern part of the Bay of Biscay and the Celtic 


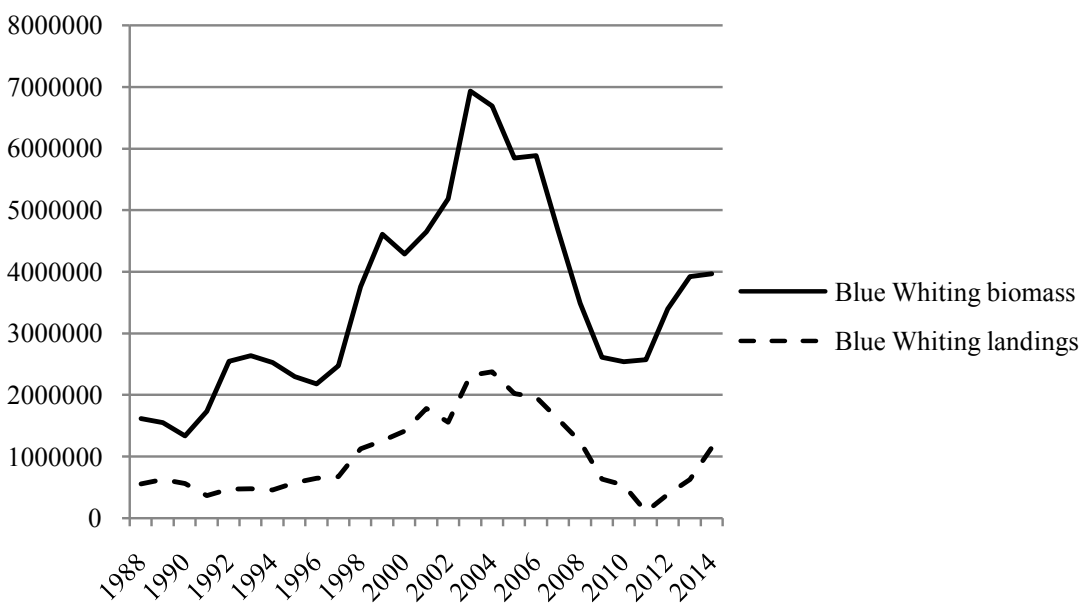

Figure 2. Blue Whiting biomass and landings (tons). 1988-2014. Source: Own compilation from ICES (2015b).

Sea. Reference [10] also studied the diet of the blue whiting, the hake, horse mackerel and the mackerel in Portuguese waters by analysing the stomach contents of samples from these species taken from along the Portuguese coast. They concluded that the blue whiting is the hake's primary prey, followed by crustaceans (Processa spp. and mysidacea). In conclusion, in the Eastern Atlantic Ocean, the blue whiting is one of the hake's main prey, although this is somewhat less true in northern waters.

\section{Predator-Prey Multispecies Model}

The model employed is based on the logic equations used by [11], which, in turn, are based on Lotka-Volterra's predator-prey model [34] [35]. By reordering it we get the following expressions:

$$
\begin{gathered}
\frac{\mathrm{d} X}{\mathrm{~d} t}=r_{m} X\left[1-\frac{X}{\bar{X}}\right]+\alpha X Y-h_{m}=F(X)+\alpha X Y-h_{m} \\
\frac{\mathrm{d} Y}{\mathrm{~d} t}=r_{L} Y\left[1-\frac{Y}{\bar{Y}}\right]-\beta Y X-h_{L}=G(Y)-\beta Y X-h_{L}
\end{gathered}
$$

where $X$ is the predator's biomass, $Y$ is the prey's biomass; $r_{m}$ and $r_{L}$ are the intrinsic population growth rates for both species, respectively; $\bar{X}$ and $\bar{Y}$ the environmental charged capacities for both species; $h_{m}$ and $h_{L}$ the respective catches, and $\alpha$ and $\beta$ the fish stock interaction coefficients.

Unlike [11], and given that trawl fleet generally depend on stock density [36], we can assume unit costs that depend on the corresponding biomass. Thus, the function of fishery's net benefits at moment $t$, is defined as:

$$
\pi\left(X, Y, h_{m}, h_{L}\right)=\left(P_{m}-C(X)\right) h_{m}(t)+\left(P_{L}-C_{L}(Y)\right) h_{L}(t)
$$

where $P_{m}$ and $P_{L}$ are the unit prices of hake and blue whiting, and $C_{m}(X)$ and $C_{L}(Y)$ the respective catch unit costs. The objective function selected for the control problem of fisher under centralised management (single owner) is: 


$$
J=\int_{0}^{\infty} \mathrm{e}^{-\rho t} \pi\left[X(t), Y(t), h_{m}(t), h_{L}(t)\right] \mathrm{d} t
$$

where $\rho$ stands for the social discount rate. The optimal feasible controls, $h_{m}(t)=$ $h_{m}^{*}$ and $h_{L}(t)=h_{L}^{*}$, will be the ones that maximise the objective function while satisfying the conditions of the problem:

$$
\begin{aligned}
& \max \int_{0}^{\infty} \mathrm{e}^{-\rho t}\left[\left(P_{m}-C_{m}(X)\right) h_{m}(t)+\left(P_{L}-C_{L}(Y)\right) h_{L}(t)\right] \mathrm{d} t \\
& \text { s.t. } \frac{\mathrm{d} X}{\mathrm{~d} t}=F(X)+\alpha X Y-h_{m} \\
& \frac{\mathrm{d} Y}{\mathrm{~d} t}= G(Y)-\beta Y X-h_{L} \\
& 0 \leq h_{m}(t) \leq h_{m} \max \\
& 0 \leq h_{L}(t) \leq h_{L} \max \\
& 0<X(t) \\
& 0<Y(t)
\end{aligned}
$$

Since we do not yet know if the dynamics of both stocks will actually fit the quadratic form and in order to simplify calculations, we opted for the generic functions $F(X)$ and $G(Y)$ in problem (5) by incorporating the term of interaction between the two species. The Hamiltonian function $H$. corresponding to the management problem is based on the following expression:

$$
\begin{aligned}
H & {\left[X(t), Y(t), h_{m}(t), h_{L}(t), t ; \lambda_{1}(t), \lambda_{2}(t)\right] } \\
= & \mathrm{e}^{-\rho t}\left[\left(P_{m}-C_{m}(X)\right) h_{m}(t)+\left(P_{L}-C_{L}(Y)\right) h_{L}(t)\right] \\
& +\lambda_{1}(t)\left[F(X)-h_{m}(t)+\alpha X Y\right]+\lambda_{2}(t)\left[G(Y)-h_{L}(t)-\beta Y X\right]
\end{aligned}
$$

where $\lambda_{1}$ and $\lambda_{2}$ represent the respective shadow prices of the predator and prey. The first order conditions associated with (6) are based on:

$$
\begin{gathered}
\frac{\mathrm{d} H(.)}{\mathrm{d} h_{m}}=0 ; \frac{\mathrm{d} H(.)}{\mathrm{d} h_{L}}=0 \\
\frac{\mathrm{d} \lambda_{1}}{\mathrm{~d} t}=\lambda_{1}=-\frac{\mathrm{d} H(.)}{\mathrm{d} X} ; \frac{\mathrm{d} \lambda_{2}}{\mathrm{~d} t}=\lambda_{2}=-\frac{\mathrm{d} H(.)}{\mathrm{d} Y} \\
\frac{\mathrm{d} X}{\mathrm{~d} t}=\dot{X}=\frac{\mathrm{d} H(.)}{\mathrm{d} \lambda_{1}} ; \frac{\mathrm{d} Y}{\mathrm{~d} t}=\dot{Y}=\frac{\mathrm{d} H(.)}{\mathrm{d} \lambda_{2}}
\end{gathered}
$$

Following [37] [38] [39] and [40], and adapting it to the multispecies case, we obtain the following equilibrium equations:

$$
\begin{aligned}
& {\left[F^{\prime}\left(X_{u}\right)+\alpha Y_{u}\right]-\frac{\left[P_{L}-C_{L}\left(Y_{u}\right)\right] \beta Y_{u}+C_{m}^{\prime}\left(X_{u}\right)\left[F\left(X_{u}\right)+\alpha X_{u} Y_{u}\right]}{\left(P_{m}-C_{m}\left(X_{u}\right)\right)}=\rho} \\
& {\left[G^{\prime}\left(Y_{u}\right)-\beta X_{u}\right]+\frac{\left[P_{m}-C_{m}\left(X_{u}\right)\right] \alpha X_{u}-C_{L}^{\prime}\left(Y_{u}\right)\left[G\left(Y_{u}\right)-\beta Y_{u} X_{u}\right]}{\left(P_{L}-C_{L}\left(Y_{u}\right)\right)}=\rho}
\end{aligned}
$$


Equation (10) and Equation (11) constitute a system whose solution would give us the steady state optimal biomass levels for both species, $X_{u}=X^{\star}$ and $Y_{u}=$ $Y^{\star}$.

\section{Application to Hake and Blue Whiting Fisheries}

In order to apply the previous multispecies model to the case study, we must first determine the functional form of the dynamics of each fish stock. To do so, econometric regressions were made using the ordinary least squares (OLS) method based on hake and blue whiting biomass and catch data for the 1988-2014 period, which are published by ICES [41] [42]. In addition to the standard quadratic form, the following exponential and potential expressions, respectively, were considered for both species:

$$
\begin{gathered}
\dot{X}=\alpha X-\beta X^{2}+\gamma X Y-h \\
\dot{X}=\alpha \mathrm{e}^{\beta X}+\gamma X Y-h \\
\dot{X}=\alpha \mathrm{e}^{\beta X+\gamma X Y}-h
\end{gathered}
$$

The results of the econometric estimates are shown in Table 1. Overall, these expressions provide significant parameters for the levels that are normally accepted in statistical inference hypothesis testing (see Table 1). To compare these expressions, we used the adjusted coefficient of determination ( $R^{2}$ adjusted), which covers the econometric model's explicative capacity (the maximum value of all of them), and the Akaike criteria (AIC).

The results indicate that the quadratic form is most appropriate for the growth functions of hake and blue whiting, with a value of $R^{2}$ adjusted from 0.992661 and 0.984233 , respectively (where this value is below 0.87 in all the other cases), and higher AIC. In addition, only the quadratic forms have a positive predator-prey interaction coefficient for hake while at the same time negative for blue whiting, which would be typical of a trophic relationship. Therefore the following quadratic expressions were selected to create growth functions for hake and blue whiting:

$$
\begin{aligned}
\dot{X} & =\alpha X-\beta X^{2}+\gamma X Y-h_{m} \\
& =1.98802 X-0.0000029429 X^{2}+0.00000000183165 X Y-h_{m} \\
\dot{Y} & =\varphi Y-\mu Y^{2}-\omega X Y-h_{L} \\
& =1.49868 Y-0.0000000821632 Y^{2}-0.00000312827 X Y-h_{L}
\end{aligned}
$$

As for the cost functions, we obtained average catch cost data for both species for the entire European fleet involved in this fishery, based on Scientific Technical and Economic Committee for Fisheries (STECF) annual economic reports on European fleets during 2011-2014. The expressions that best fit the data are as follows:

$$
\begin{gathered}
C_{m}(X)=a-b X ; C_{m}^{\prime}(X)=-b \\
C_{L}(Y)=c-d Y ; C_{L}^{\prime}(Y)=-d
\end{gathered}
$$


Table 1. Results from econometric estimations for stock dynamic.

\begin{tabular}{|c|c|c|c|c|c|c|}
\hline \multirow{2}{*}{$\begin{array}{c}\text { Coefficient/ } \\
\text { Statistic }\end{array}$} & \multicolumn{2}{|c|}{ Quadratic function } & \multicolumn{2}{|c|}{ Exponential function } & \multicolumn{2}{|c|}{ Power function } \\
\hline & Hake & $\begin{array}{c}\text { Blue } \\
\text { whiting }\end{array}$ & Hake & $\begin{array}{c}\text { Blue } \\
\text { whiting }\end{array}$ & Hake & $\begin{array}{l}\text { Blue } \\
\text { whiting }\end{array}$ \\
\hline $\mathrm{x}$ & $\begin{array}{l}1.98802 \\
(0.0000)\end{array}$ & & $\begin{array}{c}6.2841 \mathrm{e}^{-0.5} \\
(0.0263)\end{array}$ & & & \\
\hline sq_x & $\begin{array}{c}-2.94291 \\
\mathrm{e}^{-0.6}(0.0000)\end{array}$ & & & & & \\
\hline xy & $\begin{array}{c}1.83165 \mathrm{e}^{-0.9} \\
(0.1873)\end{array}$ & $\begin{array}{c}-3.12827 \\
\mathrm{e}^{-0.6}(0.2005)\end{array}$ & $\begin{array}{c}7.13 \mathrm{e}^{-0.12} \\
(0.3646)\end{array}$ & $\begin{array}{c}8.2693 \mathrm{e}^{-0.12} \\
(0.1333)\end{array}$ & & \\
\hline $\mathrm{y}$ & & $\begin{array}{l}1.49868 \\
(0.0000)\end{array}$ & & $\begin{array}{c}2.85098 \mathrm{e}^{-0.6} \\
(0.0000)\end{array}$ & & \\
\hline sq_y & & $\begin{array}{c}-8.21632 \\
\mathrm{e}^{-0.8}(0.2226)\end{array}$ & & & & \\
\hline xyL_x & & & & & $\begin{array}{l}2.01014 \mathrm{e}^{-0.12} \\
\quad(0.0000)\end{array}$ & \\
\hline xyL_y & & & & & & $\begin{array}{c}2.03629 \mathrm{e}^{-0.12} \\
\quad(0.0000)\end{array}$ \\
\hline $\mathrm{R}^{2}$ & 0.993225 & 0.985446 & 0.795283 & 0.870396 & 0.723472 & 0.742810 \\
\hline $\mathrm{R}^{2}$ adjusted & 0.992661 & 0.984233 & 0.787094 & 0.865211 & 0.723472 & 0.742810 \\
\hline log-likelihood & -300.2893 & -398.1802 & -83.93742 & -84.31655 & -87.99664 & -93.56849 \\
\hline Rho & 0.488674 & 0.439072 & 0.967083 & 0.876967 & 0.985883 & 0.978454 \\
\hline $\begin{array}{c}\text { Akaike } \\
\text { criteria (AIC) }\end{array}$ & 606.5787 & 802.3605 & 171.8748 & 172.6331 & 177.9333 & 189.1370 \\
\hline $\begin{array}{l}\text { Durbin- } \\
\text { Watson }\end{array}$ & 0.990641 & 1.120075 & 0.062242 & 0.169199 & 0.068781 & 0.075548 \\
\hline
\end{tabular}

Note: Growth functions with constant term were also estimated; however it provided statistically non-significant results. p-values between brackets. Observations: 27.

By including the parameters of functions (15)-(18) in expressions (10) and (11) of the previous section and performing the calculations, we get the following expressions:

$$
\begin{gathered}
{\left[\left(\alpha-2 \beta X_{u}\right)+\gamma Y_{u}\right]-\frac{\left[P_{L}-\left(c-d Y_{u}\right)\right] \omega Y_{u}+(-b)\left[\left(\alpha X_{u}-\beta X_{u}^{2}\right)+\gamma X_{u} Y_{u}\right]}{P_{m}-\left(a-b X_{u}\right)}=\rho(} \\
{\left[\left(\varphi-2 \mu Y_{u}\right)-\omega X_{u}\right]+\frac{\left[P_{m}-\left(a-b X_{u}\right)\right] \gamma X_{u}-(-d)\left[\left(\varphi Y_{u}-\mu Y_{u}^{2}\right)+\omega Y_{u} X_{u}\right]}{P_{L}-\left(c-d Y_{u}\right)}=\rho}
\end{gathered}
$$

And levels corresponding to the maximum sustainable yield (MSY) are given by the following expressions:

$$
\begin{gathered}
X_{M S Y}=\frac{\frac{\alpha}{\gamma}-\frac{\varphi}{2 \mu}}{\frac{-\omega}{2 \mu}+\frac{2 \beta}{\gamma}} \\
Y_{M S Y}=\frac{\alpha-2 \beta X_{M S Y}}{\gamma}
\end{gathered}
$$


As for prices, we did not obtain any data on the European fleet. Based on the annual price data for first sale in the Spanish market for both species during the 2001-2014 period, we have estimated the average catch unit price in constant 2014 monetary units $\left(P_{m}=4619.23 € /\right.$ tonne; $P_{L}=399.13 € /$ tonne $)$. Given that these prices may differ from those obtained from other European countries, various price scenarios have been proposed to obtain the equilibrium values. Additionally, an initial discount rate $(\rho) 5 \%$ was used. The catch cost functions have adopted the following expressions: $C_{m}\left(X_{t}\right)=2964.1-0.0055 X_{t}$ for hake and $C_{L}\left(Y_{t}\right)=413.8-0.00004 Y_{t}$ for blue whiting.

MSY levels for this model are 336,922 and 2,706,178 tonnes, respectively, for hake and blue whiting. The results for biomass, catches and net benefits using different discount rate values are shown in Table 2. The optimal level of biomass of the predator (hake) is below the $M S Y$ level, while the optimal biomass of prey (blue whiting) is exceeding the $M S Y$ biomass. Likewise, as one can see, as the discount rate increases, the biomass level of both species decreases, while catches increase. The net benefits derived from fishing both species would increase by increasing the discount rate, although the net benefits from blue whiting fishing increase in greater proportion. The results of the sensitivity analysis with regard to fish prices, by changing the price of a single species or for both stocks, and under a discount rate of 5\%, are shown in Table 3. In general, the greatest increase in net benefits is obtained when the prices of both species are raised simultaneously.

\section{Conclusions}

A better understanding of trophic relationships among fish stocks allows to develop multispecies fishery management models, which is the category under which most European fisheries fall. This paper studies a fishery with two of the European fleet's target species that display significant ecological predatory interdependence. The trophic interaction between the predator (hake) and prey (blue whiting) is added to the management problem to jointly determine fishing quotas for both species. This interaction may be considered as a biological externality. By adding that externality to the fishery management problem, the

Table 2. Optimum levels under different discount rates.

\begin{tabular}{cccccccc}
\hline \multicolumn{2}{c}{ Biomass } & \multicolumn{3}{c}{ Catches } & \multicolumn{2}{c}{ Net benefits } \\
\hline & Hake & $\begin{array}{c}\text { Blue } \\
\text { Whiting }\end{array}$ & Hake & $\begin{array}{c}\text { Blue } \\
\text { Whiting }\end{array}$ & Hake & $\begin{array}{c}\text { Blue } \\
\text { Whiting }\end{array}$ & Total \\
\hline 0.00 & 290.5 & 4882.3 & 41.3 & 921.6 & 134.2 & 166.5 & 300.7 \\
0.05 & 281.0 & 4871.5 & 47.8 & 1068.7 & 152.9 & 192.6 & 345.5 \\
0.10 & 275.0 & 4812.8 & 51.6 & 1169.4 & 163.4 & 208.0 & 371.3 \\
0.15 & 269.0 & 4753.0 & 55.2 & 1267.4 & 172.9 & $222 . .4$ & 395.3 \\
\hline
\end{tabular}

Weights in thousand tonnes and benefits in $€ \times 10^{6} . P_{m}=4619 € /$ tonne; $P_{L}=399 € /$ tonne. 
Table 3. Optimum levels under different prices.

\begin{tabular}{cccccccc}
\hline & \multicolumn{2}{c}{ Biomass } & \multicolumn{2}{c}{ Catches } & \multicolumn{3}{c}{ Net benefits } \\
& Hake & $\begin{array}{c}\text { Blue } \\
\text { Whiting }\end{array}$ & Hake & $\begin{array}{c}\text { Blue } \\
\text { Whiting }\end{array}$ & Hake & $\begin{array}{c}\text { Blue } \\
\text { Whiting }\end{array}$ & Total \\
\hline$P_{m}=4500 ; P_{L}=399$ & 287.5 & 4755.9 & 43.3 & 991.8 & 135.0 & 174.1 & 309.1 \\
$P_{m}=4700 ; P_{L}=399$ & 278.0 & 4931.9 & 49.7 & 1103.8 & 162.4 & 201.6 & 364.0 \\
$P_{m}=4619 ; P_{L}=350$ & 270.0 & 5483.0 & 54.9 & 1116.0 & 172.5 & 173.6 & 346.1 \\
$P_{m}=4619 ; P_{L}=450$ & 285.5 & 4188.7 & 44.4 & 1094.9 & 143.2 & 223.1 & 366.3 \\
$P_{m}=4700 ; P_{L}=450$ & 264.0 & 4710.0 & 58.0 & 1346.3 & 184.9 & 302.4 & 487.3 \\
$P_{m}=4500 ; P_{L}=350$ & 310.0 & 5110.1 & 26.4 & 557.3 & 85.5 & 78.4 & 163.8 \\
$P_{m}=4700 ; P_{L}=350$ & 278.0 & 5450.0 & 50.0 & 987.7 & 163.3 & 200.8 & 364.1 \\
$P_{m}=4500 ; P_{L}=450$ & 290.0 & 4100.0 & 41.2 & 1043.9 & 129.0 & 209.0 & 338.0 \\
\hline
\end{tabular}

Weights in thousand tonnes and benefits in $€ \times 10^{6} . \rho=0.05$.

results show that both species are being over-fished, although hake is more so than blue whiting. This could place the ecological equilibrium that exists between the two species at risk, as well as alter the ecosystem overall.

Furthermore, as a consequence of ecological interdependence between the two species, the $M S Y$ level of the predator (hake) is higher in this model than the estimated level by ICES (about 200 thousand tonnes; [41]), while the MSY for the prey is slightly lower (approx. 3800 thousand tonnes; [42]). The TACs set by the EU in 2015 were approximately 105 and 1260 thousand tonnes. The results obtained from the predator-prey model show that catches should fall below the TAC levels set for each species. It is important to keep these interactions in mind when establishing the catch levels, given that the catch level for one species will have repercussions on the growth of the other and, therefore, on the sustainability of the marine environment and fishing activity in the long run.

\section{Acknowledgements}

The authors acknowledge the comments from participants in the 18th IIFET Conference and Juan Surís-Regueiro to improve this research, and the financial support from FEDER and Xunta de Galicia (GRC2014/022) and from the Spanish Ministry of Economy and Competitiveness (ECO2014-52412-R and ECO2013-44436-R).

\section{References}

[1] Botsford, L.W., Castilla, J.C. and Peterson, C.H. (1997) The Management of Fisheries and Marine Ecosystems. Science, 277, 509-515. https://doi.org/10.1126/science.277.5325.509

[2] Mahe, K., Amara, R., Bryckaert, T., Kacher, M. and Brylinski, J.M. (2007) Ontogenetic and Spatial Variation in the Diet of Hake (Merluccius merluccius) in the Bay of Biscay and the Celtic Sea. ICES Journal of Marine Science, 64, 1210-1219. 
[3] May, R.M., Beddington, J.R., Clark, C.W., Holt, S.J. and Laws, R.M. (1979) Management of Multispecies Fisheries. Science, 205, 267-277. https://doi.org/10.1126/science.205.4403.267

[4] Rothschild, B.J. (1991) Multispecies Interactions on Georges Bank. ICES Marine Science Symposia, 193, 86-92.

[5] Neuenfeldt, S. and Koster, F.W. (2000) Trophodynamic Control on Recruitment Success in Baltic Cod: The Influence of Cannibalism. ICES Journal of Marine Science, 57, 300-309. https://doi.org/10.1006/jmsc.2000.0647

[6] Wespestad, V., Fritz, L., Ingraham, W. and Megrey, B. (2000) On Relationships between Cannibalism, Climate Variability, Physical Transport, and Recruitment Success of Bering Sea Walleye Pollock (Theragra chalcogramma). ICES Journal of Marine Science, 57, 268-274. https://doi.org/10.1006/jmsc.2000.0640

[7] Tsou, T.S. and Collie, J.S. (2001) Predation-Mediated Recruitment in the Georges Bank Fish Community. ICES Journal of Marine Science, 58, 994-1001. https://doi.org/10.1006/jmsc.2001.1088

[8] May, R.M. (1984) Exploitation of Marine Communities. Report of the Dahlem Workshop on Exploitation of Marine Communities. DahlemKonferenzen. Springer-Verlag, Berlin. https://doi.org/10.1007/978-3-642-70157-3

[9] Guichet, R. (1995) The Diet of European Hake (Merluccius merluccius) in the Northern Part of the Bay of Biscay. ICES Journal of Marine Science, 52, 21-31.

[10] Cabral, H.N. and Murta, A.G. (2002) The Diet of Blue Whiting, Hake, Horse Mackerel and Mackerel off Portugal. Journal of Applied Ichthyology, 18, 14-23. https://doi.org/10.1046/j.1439-0426.2002.00297.x

[11] Brown, G., Berger, B. and Ikiara, M. (2005) A Predator-Prey Model with an Application to Lake Victoria Fisheries. Marine ResourceEconomics, 20, 221-247. https://doi.org/10.1086/mre.20.3.42629473

[12] Seijo, J.C., Defeo, O. and Salas, S. (1997) Bioeconomía Pesquera. Teoría, Modelación y Manejo. FAO Documento Técnico de Pesca. No. 368. FAO, Roma.

[13] FAO (1978) Fishery Commodity Situation and Outlook. FAO: Committee on Fisheries, 12th Session, COFI/78/inf. 5, 1-15.

[14] Huppert, D. (1979) Implications of Multipurpose Fleets and Mixed Stocks for Control Policies. Journal of the Fisheries Research Board of Canada, 36, 845-854. https://doi.org/10.1139/f79-122

[15] Clark, C.W. (1985) Bioeconomic Modelling of Fisheries Management. J. Wiley \& Sons, New York.

[16] Fletcher, J.J., Howitt, R.E. and Johnston, W.E. (1988) Management of Multipurpose Heterogeneous Fishing Fleets under Uncertainty. Marine Resource Economics, 4, 249-270. https://doi.org/10.1086/mre.4.4.42629694

[17] Anderson, L.G. (1975) Analysis of Open-Access Commercial Exploitation and Maximum Economic Yield in Biological and Technologically Interdependent Fisheries. Journal of the Fisheries Research Board of Canada, 32, 1825-1842. https://doi.org/10.1139/f75-217

[18] Mitchell, C.L. (1982) Bioeconomics of Multispecies Exploitation in Fisheries: Management Implications. Canadian Special Publication of Fisheries and Aquatic Sciences, 59, 157-162.

[19] Keddy, P.A. (1989) Competition. Chapman \& Hall, London. https://doi.org/10.1007/978-94-010-9011-7

[20] Giller, P.S. (1984) Community Structure and the Niche. Chapman \& Hall, London. 
https://doi.org/10.1007/978-94-009-5558-5

[21] Begon, M., Harper, J.L. and Townsend, C.R. (1990) Ecology. Individuals. Populations and Communities. Blackwell Scientific Publications, Boston.

[22] Ekerhovd, N.-A. and Steinshamn, S.I. (2016) Economic Benefits of Multi-Species Management: The Pelagic Fisheries in the Northeast Atlantic. Marine Resource Economics, 31, 193-210. https://doi.org/10.1086/685383

[23] Larkin, P.A. (1982) Aquaculture in North America: an Assessment of Future Prospects. Canadian Journal of Fisheries and Aquatic Sciences, 39, 151-154. https://doi.org/10.1139/f82-016

[24] Majkowski, J. (1982) Usefulness and Applicability of Sensitivity Analysis in a Multispecies Approach to Fisheries Management. In: Pauly, D. and Murphy, G.I., Eds., Theory and Management of Tropical Fisheries, ICLARM Conference Proceedings, Vol. 9, 149-165.

[25] Sugihara, G., García, S., Gulland, J.A., Lawton, J.H., Maske, H., Paine, R.T., Platt, T., Rachor, E., Rothschild, B.J., Ursin, E.A. and Zeitzschel, B.F.K. (1984) Ecosystem Dynamics. In: May, R.M., Ed., Exploitation of Marine Communities, Report of the Dahlem Workshop on Exploitation of Marine Communities.

https://doi.org/10.1007/978-3-642-70157-3_6

[26] Link, J.S. (2009) Ecosystem-Based Fisheries Management: Comforting Tradeoffs. Cambridge University Press, New York.

[27] Flaaten, O. (1991) Bioeconomics of Sustainable Harvest of Competing Species. Journal of Environmental Economics and Management, 20, 163-180.

[28] Ströbele, W.J. and Wacker, H. (1991) The Concept of Sustainable Yield in MultiSpecies Fisheries. Ecological Modelling, 53, 61-74.

[29] European Commission (2004) Council Regulation (EC) No. 811/2004 of 21 April 2004, Establishing Measures for the Recovery of the Northern Hake Stock. Official Journal of the European Union, L150, 1-11.

[30] European Commission (2005) Council Regulation (EC) No 2166/2005 of 20 December 2005, Establishing Measures for the Recovery of the Southern Hake and Norway Lobster Stocks in the Cantabrian Sea and Western Iberian Peninsula and Amending Regulation (EC) No 850/98 for the Conservation of Fishery Resources through Technical Measures for the Protection of Juveniles of Marine Organisms. Official Journal of the European Union, L345, 5-10.

[31] Sánchez, F. (1993) Las Comunidades de Peces de la Plataforma del Cantábrico. Publicación Especial del Instituto Español de Oceanografía, 13.

[32] Velasco, F. and Olaso, I. (1988) European Hake Merluccius merluccius (L. 1758) Feeding in the Cantabrian Sea: Seasonal, Bathymetric and Length Variations. Fisheries Research, 38, 33-44.

[33] Gonzalez, R., Olaso, I. and Pereda, P. (1985) Contribución al Conocimiento de la Alimentación de la Merluza (Merluccius merluccius L.) en la Plataforma Continental de Galicia y del Cantábrico. Boletín del Instituto Español de Oceanografía, 2, 49-60.

[34] Volterra, V. (1926) Fluctuations in the Abundance of Species, Considered Mathematically. Nature, 118, 558-560. https://doi.org/10.1038/118558a0

[35] Lotka, A.J. (1932) The Growth of Mixed Populations: Two Species Competing for a Common Food Supply. Journal of the Washington Academy of Sciences, 22, 461 469.

[36] Eide, A., Skjold, F., Olsen, F. and Flaaten, O. (2003) Harvest Functions: The Norwe- 
gian Bottom Trawl Cod Fisheries. Marine ResourceEconomics, 18, 81-93. https://doi.org/10.1086/mre.18.1.42629384

[37] Clark, C.W. (1976) Mathematical Bioeconomics-The Optimal Management of Renewable Resources. J. Wiley and Sons, Sussex.

[38] Clark, C.W. and Munro, G.R. (1975) The Economics of Fishing and Modern Capital Theory: A Simplified Approach. Journal of Environmental Economics and Management, 5, 96-106.

[39] Rozonoer, L.I. (1959) L.S. Pontryagin's Maximum Principle in Optimal Control Theory. Automat, i Telemekh, 20, 1320-1334, 1441-1448, 1561-1578.

[40] Spence, M. and Starrett, D. (1975) Most Rapid Approach Paths in Accumulation Problems. International Economic Review, 16, 388-403. https://doi.org/10.2307/2525821

[41] ICES (2015a) Report of ICES Advice on Fishing Opportunities, Catch, and Effort. ICES Advisory Committee, ICES Advice. Book 7. http://www.ices.dk

[42] ICES (2015b) Report of ICES Advice on Fishing Opportunities, Catch, and Effort. ICES Advisory Committee, ICES Advice. Book 9. http://www.ices.dk

Submit or recommend next manuscript to SCIRP and we will provide best service for you:

Accepting pre-submission inquiries through Email, Facebook, LinkedIn, Twitter, etc. A wide selection of journals (inclusive of 9 subjects, more than 200 journals) Providing 24-hour high-quality service User-friendly online submission system Fair and swift peer-review system Efficient typesetting and proofreading procedure Display of the result of downloads and visits, as well as the number of cited articles Maximum dissemination of your research work

Submit your manuscript at: http://papersubmission.scirp.org/

Or contact nr@scirp.org 